Supporting Information

Bifunctional Fe for Induced Graphitization and Catalytic Ozonation Based on a $\mathrm{Fe} / \mathrm{N}$-doped Carbon- $\mathrm{Al}_{2} \mathrm{O}_{3}$ Framework: Theoretical Calculations Guided

\title{
Catalyst Design and Optimization
}

Changpei Ouyang ${ }^{\dagger}$, Kajia Wei ${ }^{\dagger, \dagger}$, Xia Huang $^{\dagger, \S}$, Mohamed Gamal El-Din $^{\perp}$, Xiaoyuan Zhang ${ }^{*}, \dagger, \S$

†State Key Joint Laboratory of Environment Simulation and Pollution Control, School of Environment, Tsinghua University, Beijing 100084, China

\$School of Environmental and Biological Engineering, Nanjing University of Science and Technology, Nanjing 210095, China

§International Joint Laboratory on Low Carbon Clean Energy Innovation, Tsinghua University, Beijing 100084, China

${ }^{\perp}$ Department of Civil and Environmental Engineering, University of Alberta, Edmonton, Alberta Canada T6G 1H9

* Corresponding author: Xiaoyuan Zhang

E-mail address: zhangxiaoyuan@tsinghua.edu.cn

Prepared for Environmental Science \& Technology

Pages 21; Tables 13; Figures 18 


\section{Supplemental Materials and Methods}

Details of $\boldsymbol{R}_{c t}$ experiments. In order to quantify ozone concentration accurately, an ozone stock solution was prepared by continuous ozone bubbling into $500 \mathrm{~mL}$ DI water in an ice bath for more than $30 \mathrm{~min}$ to reach equilibrium. A buffered solution $(\mathrm{pH}=6.7)$ with $\sim 29 \mu \mathrm{M}$ dissolved ozone and $0.5 \mu \mathrm{M} p \mathrm{CBA}$ was prepared for the detection of the $\cdot \mathrm{OH}^{1,2}$ The amount of dissolved $\mathrm{O}_{3}$ was determined according to the Indigo method. ${ }^{3}$ The $p$ CBA concentration was measured using an Agilent high performance liquid chromatography (HPLC) apparatus with an Eclipse XDB-C18 column (4.6 mm $\times 150$ $\mathrm{mm}, 5 \mu \mathrm{m}$, Waters, USA).

Details of GC-MS Methods. The sampled water was filtered through a $0.45 \mu \mathrm{m}$ membrane, and was subsequently mixed with 100 dichloromethane $\left(\mathrm{CH}_{2} \mathrm{Cl}_{2}\right)$ and stabilized to get the extracted liquid. The extracted liquid was concentrated to $5 \mathrm{~mL}$ with a rotary evaporator, and then was mixed with 1:1 n-hexane for a second concentration to $0.5 \mathrm{~mL}$. Then the concentrated sample was analyzed by an Agilent 7890A-5975 GC-MS which used a DB-5MS column $(30 \mathrm{~m} \times 0.25 \mathrm{~mm} \times 0.25 \mu \mathrm{m})$. The injection volume to GC-MS was $1 \mu \mathrm{L}$. The temperature was set at $80{ }^{\circ} \mathrm{C}$ for $5 \mathrm{~min}$ and $280{ }^{\circ} \mathrm{C}$ for $20 \mathrm{~min}$, and the heating rate was $5^{\circ} \mathrm{C} / \mathrm{min}$. 


\section{Supplemental Results and Discussion}

Table S1. Details of the catalysts' preparation in this work

\begin{tabular}{|c|c|c|c|}
\hline Sample & $\begin{array}{c}\mathrm{C} \text { addition } \\
\text { mmol g-1 }^{-1}\left(\mathrm{Al}_{2} \mathrm{O}_{3}\right)\end{array}$ & $\begin{array}{c}\mathrm{Fe} / \mathrm{N} \text { addition } \\
\mathrm{mmol} \mathrm{g}^{-1}\left(\mathrm{Al}_{2} \mathrm{O}_{3}\right)\end{array}$ & Pyrolysis \\
\hline $\mathrm{Al}_{2} \mathrm{O}_{3}$ & 0 & 0 & 1 \\
\hline $\mathrm{Fe}-\mathrm{Al}_{2} \mathrm{O}_{3}$ & 0 & $\begin{array}{l}\text { ferric citrate } \\
\quad \sim 0.32\end{array}$ & in air at $600{ }^{\circ} \mathrm{C}$ for $4 \mathrm{~h}$ \\
\hline CAF & $\begin{array}{l}\text { Glucose } \\
\sim 0.85\end{array}$ & 0 & in $\mathrm{Ar}$ at $600{ }^{\circ} \mathrm{C}$ for $4 \mathrm{~h}$ \\
\hline $\mathrm{Fe}-\mathrm{CAF}$ & $\begin{array}{l}\text { Glucose } \\
\sim 0.85\end{array}$ & $\begin{array}{l}\text { ferric citrate } \\
\quad \sim 0.32\end{array}$ & in $\mathrm{Ar}$ at $600{ }^{\circ} \mathrm{C}$ for $4 \mathrm{~h}$ \\
\hline Fe-N-CAF- $l$ & $\begin{array}{l}\text { Glucose } \\
\sim 0.85\end{array}$ & $\begin{array}{l}\text { ferric ammonium citrate } \\
\qquad 0.22\end{array}$ & in Ar at $600{ }^{\circ} \mathrm{C}$ for $4 \mathrm{~h}$ \\
\hline Fe-N-CAF- $h$ & $\begin{array}{l}\text { Glucose } \\
\sim 0.85\end{array}$ & $\begin{array}{l}\text { ferric ammonium citrate } \\
\qquad 0.22\end{array}$ & $\begin{array}{l}\text { in air at } 200^{\circ} \mathrm{C} \text { for } 2 \mathrm{~h} \\
\text { and then in } \mathrm{Ar} \text { at } 600^{\circ} \mathrm{C} \text { for } 4 \mathrm{~h}\end{array}$ \\
\hline
\end{tabular}

Table S2. Mulliken charges of the central Fe atom of different $\mathrm{Fe}-\mathrm{N}_{\mathrm{x}} \mathrm{O}_{\mathrm{y}}-\mathrm{C}$ configurations

\begin{tabular}{cc}
\hline Sample & Mulliken charges \\
\hline $\mathrm{Fe}^{\mathrm{II}}-\mathrm{O}_{4}-\mathrm{C}$ & 3.24 \\
$\mathrm{Fe}^{\mathrm{II}}-\mathrm{N}_{2} \mathrm{O}_{2}-\mathrm{C}$ & 3.29 \\
$\mathrm{Fe}^{\mathrm{II}}-\mathrm{N}_{4}-\mathrm{C}$ & 3.67 \\
$\mathrm{Fe}^{\mathrm{III}}-\mathrm{O}_{4}-\mathrm{C}$ & 3.51 \\
$\mathrm{Fe}^{\mathrm{III}}-\mathrm{N}_{2} \mathrm{O}_{2}-\mathrm{C}$ & 4.12 \\
$\mathrm{Fe}^{\mathrm{III}}-\mathrm{N}_{3} \mathrm{O}_{1}-\mathrm{C}$ & 3.28 \\
$\mathrm{Fe}^{\mathrm{III}}-\mathrm{O}_{2} \mathrm{C}_{2}-\mathrm{C}$ & 0.19 \\
$\mathrm{Fe}^{\mathrm{III}}-\mathrm{NO}_{2} \mathrm{C}-\mathrm{C}$ & 1.93 \\
\hline
\end{tabular}

Table S3. Elements content in different catalysts

\begin{tabular}{ccccc}
\hline Sample & $\mathbf{N}(\boldsymbol{\%})$ & $\mathbf{F e}-\mathbf{N}(\boldsymbol{\%})$ & $\mathbf{F e}(\boldsymbol{\%})$ & $\mathbf{F e}^{\mathrm{III}}: \mathbf{F} \mathbf{F e}^{\mathrm{II}}$ \\
\hline $\mathrm{Fe}-\mathrm{Al}_{2} \mathrm{O}_{3}$ & - & - & 1.83 & 1.44 \\
$\mathrm{Fe}-\mathrm{CAF}$ & - & - & 1.61 & 1.03 \\
$\mathrm{Fe}-\mathrm{N}-\mathrm{CAF}-l$ & 0.44 & 23.11 & 1.49 & 1.10 \\
Fe-N-CAF- $h$ & 0.42 & 23.71 & 1.51 & 1.39 \\
\hline
\end{tabular}


Table S4. BET results of catalyst samples

\begin{tabular}{ccc}
\hline Sample & $\begin{array}{c}\text { Surface Area } \\
\mathbf{m}^{\mathbf{2}} \mathbf{g}^{\mathbf{1}}\end{array}$ & $\begin{array}{c}\text { Average Pore Diameter } \\
\mathbf{n m}\end{array}$ \\
\hline $\mathrm{Al}_{2} \mathrm{O}_{3}$ & 191.07 & 3.85 \\
$\mathrm{Fe}^{-\mathrm{Al}_{2} \mathrm{O}_{3}}$ & 174.98 & 4.35 \\
$\mathrm{CAF}$ & 160.25 & 3.85 \\
$\mathrm{Fe}-\mathrm{CAF}$ & 161.68 & 3.85 \\
$\mathrm{Fe}-\mathrm{N}-\mathrm{CAF}-l$ & 159.76 & 3.40 \\
$\mathrm{Fe}-\mathrm{N}-\mathrm{CAF}-h$ & 154.19 & 3.85 \\
\hline
\end{tabular}

Discussion. The difference in the adsorption capacity might be due to the difference in the specific surface area and pore diameter of various catalysts. According to Table S4, the surface area of $\mathrm{Al}_{2} \mathrm{O}_{3}$ was $\sim 191 \mathrm{~m}^{2} \mathrm{~g}^{-1}, \sim 20 \%$ higher than $\mathrm{CAF}\left(\sim 160 \mathrm{~m}^{2} \mathrm{~g}^{-1}\right), \mathrm{Fe}$ CAF $\left(\sim 162 \mathrm{~m}^{2} \mathrm{~g}^{-1}\right)$ and Fe-N-CAF-l $\left(\sim 160 \mathrm{~m}^{2} \mathrm{~g}^{-1}\right)$, and $\sim 24 \%$ higher than Fe-N-CAF$h\left(\sim 154 \mathrm{~m}^{2} \mathrm{~g}^{-1}\right)$. It could be inferred that the formation of graphitized carbon layer on the surface of $\mathrm{Al}_{2} \mathrm{O}_{3}$ reduced the surface area, which might result in the decrease of the adsorption capacity.

Table S5. Rate constant $(k)$ and variance $\left(R^{2}\right)$ values of COD removal with $\mathrm{O}_{3} /$ catalysts and $\mathrm{O}_{3}$ alone

\begin{tabular}{ccc}
\hline Sample & $-\boldsymbol{k}\left(\mathbf{m i n}^{-1}\right)$ & $\boldsymbol{R}^{2}$ \\
\hline No catalyst $\left(\mathrm{O}_{3}\right.$ alone $)$ & $0.021 \pm 0.001$ & 0.9975 \\
$\mathrm{Al}_{2} \mathrm{O}_{3}$ & $0.027 \pm 0.001$ & 0.9962 \\
$\mathrm{Fe}_{3} \mathrm{Al}_{2} \mathrm{O}_{3}$ & $0.034 \pm 0.001$ & 0.9962 \\
$\mathrm{CAF}$ & $0.033 \pm 0.001$ & 0.9957 \\
$\mathrm{Fe}-\mathrm{CAF}$ & $0.041 \pm 0.002$ & 0.9896 \\
$\mathrm{Fe}-\mathrm{N}-\mathrm{CAF}-l$ & $0.061 \pm 0.005$ & 0.9716 \\
$\mathrm{Fe}-\mathrm{N}-\mathrm{CAF}-h$ & $0.069 \pm 0.005$ & 0.9772 \\
\hline
\end{tabular}

Table S6. Fukui function and double descriptor (DD) of each atom of ozone

\begin{tabular}{cccc}
\hline Atom & f + & f- & DD \\
\hline Central atom & 0.26 & 0.22 & 0.04 \\
End atom 1 & 0.37 & 0.39 & -0.02 \\
End atom 2 & 0.37 & 0.39 & -0.02 \\
\hline
\end{tabular}


Table S7. HOMO and LUMO energy in different molecules

\begin{tabular}{ccccc}
\hline Molecule & HOMO- $\boldsymbol{\alpha}$ (a.u.) & LUMO- $\boldsymbol{\alpha}$ (a.u.) & HOMO- $\boldsymbol{\beta}$ (a.u.) & LUMO- $\boldsymbol{\beta}$ (a.u.) \\
\hline $\mathrm{O}_{3}$ & -0.347 & -0.214 & -0.347 & -0.214 \\
$\mathrm{Fe}^{\mathrm{II}}-\mathrm{N}_{2} \mathrm{O}_{2}-\mathrm{C}$ & -0.193 & -0.146 & -0.193 & -0.146 \\
$\mathrm{Fe}^{\mathrm{III}}-\mathrm{N}_{2} \mathrm{O}_{2}-\mathrm{C}$ & -0.265 & -0.180 & -0.218 & -0.180 \\
\hline
\end{tabular}

Table S8. The gap between HOMO of ozone and LUMO of $\mathrm{Fe}-\mathrm{N}_{2} \mathrm{O}_{2}-\mathrm{C}$

\begin{tabular}{cc}
\hline Molecule & Gap (a.u.) \\
\hline $\mathrm{O}_{3}$ and $\mathrm{Fe}^{\mathrm{II}}-\mathrm{N}_{2} \mathrm{O}_{2}-\mathrm{C}$ & 0.201 \\
$\mathrm{O}_{3}$ and $\mathrm{Fe}^{\mathrm{III}}-\mathrm{N}_{2} \mathrm{O}_{2}-\mathrm{C}$ & 0.167 \\
\hline
\end{tabular}

Table S9. The gap between HOMO of $\mathrm{Fe}-\mathrm{N}_{2} \mathrm{O}_{2}-\mathrm{C}$ and LUMO of ozone

\begin{tabular}{cc}
\hline Molecule & Gap (a.u.) \\
\hline $\mathrm{O}_{3}$ and $\mathrm{Fe}^{\mathrm{II}}-\mathrm{N}_{2} \mathrm{O}_{2}-\mathrm{C}$ & 0.021 \\
$\mathrm{O}_{3}$ and $\mathrm{Fe}^{\mathrm{III}}-\mathrm{N}_{2} \mathrm{O}_{2}-\mathrm{C}$ & 0.004 \\
\hline
\end{tabular}

Table S10. Gibbs free energy of reactant, transition state and production of $\mathrm{Fe}^{\mathrm{II}}-\mathrm{N}_{2} \mathrm{O}_{2}-$ $\mathrm{C}$ with $\mathrm{O}_{3}$

\begin{tabular}{cc}
\hline State & G (a.u.) \\
\hline Reactant & -3129.9599 \\
Transition state & -3129.9570 \\
Production & -3129.9607 \\
\hline
\end{tabular}

Table S11. Gibbs free energy of reactant, transition state and production of $\mathrm{Fe}^{\mathrm{III}}-$ $\mathrm{N}_{2} \mathrm{O}_{2}-\mathrm{C}$ with $\mathrm{O}_{3}$

\begin{tabular}{cc}
\hline State & G (a.u.) \\
\hline Reactant & -3129.7892 \\
Transition state & -3129.7871 \\
Production & -3129.7924 \\
\hline
\end{tabular}

Table S12. The leaching of Fe from different catalysts.

\begin{tabular}{cc}
\hline Sample & $\mathbf{F e}^{\dagger}\left(\boldsymbol{\mu g ~ \mathbf { ~ L } ^ { - 1 } )}\right.$ \\
\hline $\mathrm{Fe}^{-\mathrm{Al}_{2} \mathrm{O}_{3}}$ & 123.00 \\
$\mathrm{Fe}-\mathrm{N}-\mathrm{CAF}-l$ & 2.74 \\
$\mathrm{Fe}-\mathrm{N}-\mathrm{CAF}-h$ & 4.97 \\
\hline
\end{tabular}

†Condition: $250 \mathrm{ml}$ DI water, $\mathrm{O}_{3}$ concentration $\sim 100 \mathrm{mg} \mathrm{L}^{-1}$, catalyst addition $4.0 \mathrm{~g} \mathrm{~L}^{-}$ 1 , reaction time $10 \mathrm{~h}$, analysis by ICP-MS 
Table S13. Main organics in coal-gasification wastewater.

\begin{tabular}{|c|c|c|c|}
\hline Components & Formula & Molecular weight $\left(\mathrm{g} \mathrm{mol}^{-1}\right)$ & Area percent \\
\hline Heptadecane,2,6,10,15-tetramethyl- & $\mathrm{C}_{21} \mathrm{H}_{44}$ & 296.57 & 9.30 \\
\hline Eicosane & $\mathrm{C}_{20} \mathrm{H}_{42}$ & 282.55 & 6.99 \\
\hline 1-(2-trimethylsilyloxyphenyl)propan-1-one & $\mathrm{C}_{12} \mathrm{H}_{18} \mathrm{O}_{2} \mathrm{Si}$ & 222.36 & 5.69 \\
\hline 1,2-Benzenedicarboxylic acid, mono(2-ethylhexyl) ester & $\mathrm{C}_{16} \mathrm{H}_{22} \mathrm{O}_{4}$ & 278.34 & 3.63 \\
\hline Nonahexacontanoic acid & $\mathrm{C}_{69} \mathrm{H}_{138} \mathrm{O}_{2}$ & 999.83 & 2.92 \\
\hline Trimethyl(4-tert-butylphenoxy)silane & $\mathrm{C}_{13} \mathrm{H}_{22} \mathrm{OSi}$ & 222.40 & 1.70 \\
\hline Tetratetracontane & $\mathrm{C}_{44} \mathrm{H}_{90}$ & 619.19 & 1.64 \\
\hline 9-methylidenefluorene & $\mathrm{C}_{14} \mathrm{H}_{10}$ & 178.23 & 1.62 \\
\hline Benz[b]-1,4-oxazepine-4(5H)-thione, 2,3-dihydro-2,8-dimethyl- & $\mathrm{C}_{11} \mathrm{H}_{13} \mathrm{NOS}$ & 207.29 & 1.58 \\
\hline Phthalic acid 1-butyl 2-undecyl ester & $\mathrm{C}_{23} \mathrm{H}_{36} \mathrm{O}_{4}$ & 376.54 & 1.51 \\
\hline 4,4-diphenyl-2-pentyne & $\mathrm{C}_{17} \mathrm{H}_{16}$ & 220.31 & 1.35 \\
\hline Acridine,2-ethyl & $\mathrm{C}_{15} \mathrm{H}_{13} \mathrm{~N}$ & 207.27 & 1.22 \\
\hline trimethylsilyl octadecanoate & $\mathrm{C}_{21} \mathrm{H}_{44} \mathrm{O}_{2} \mathrm{Si}$ & 356.66 & 1.10 \\
\hline 4-Ethyl-5-octyl-2,2-bis(trifluoromethyl)-1,3-dioxolane & $\mathrm{C}_{15} \mathrm{H}_{24} \mathrm{~F}_{6} \mathrm{O}_{2}$ & 350.34 & 1.06 \\
\hline
\end{tabular}




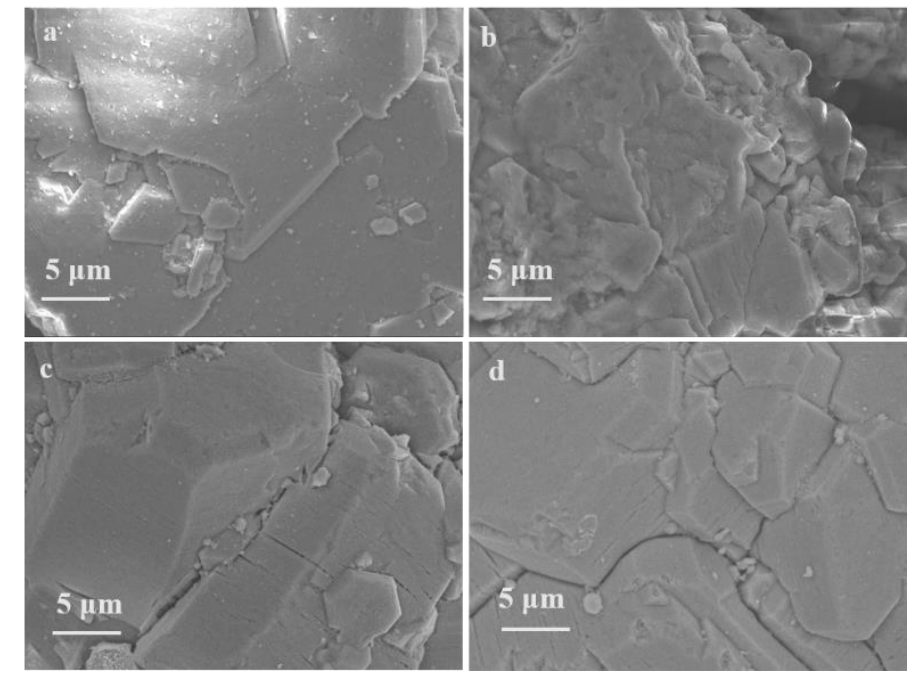

Figure S1. SEM images of $\mathrm{Al}_{2} \mathrm{O}_{3}$ (a), CAF (b), Fe-N-CAF- $l$ (c) and Fe-N-CAF- $h$ (d). 

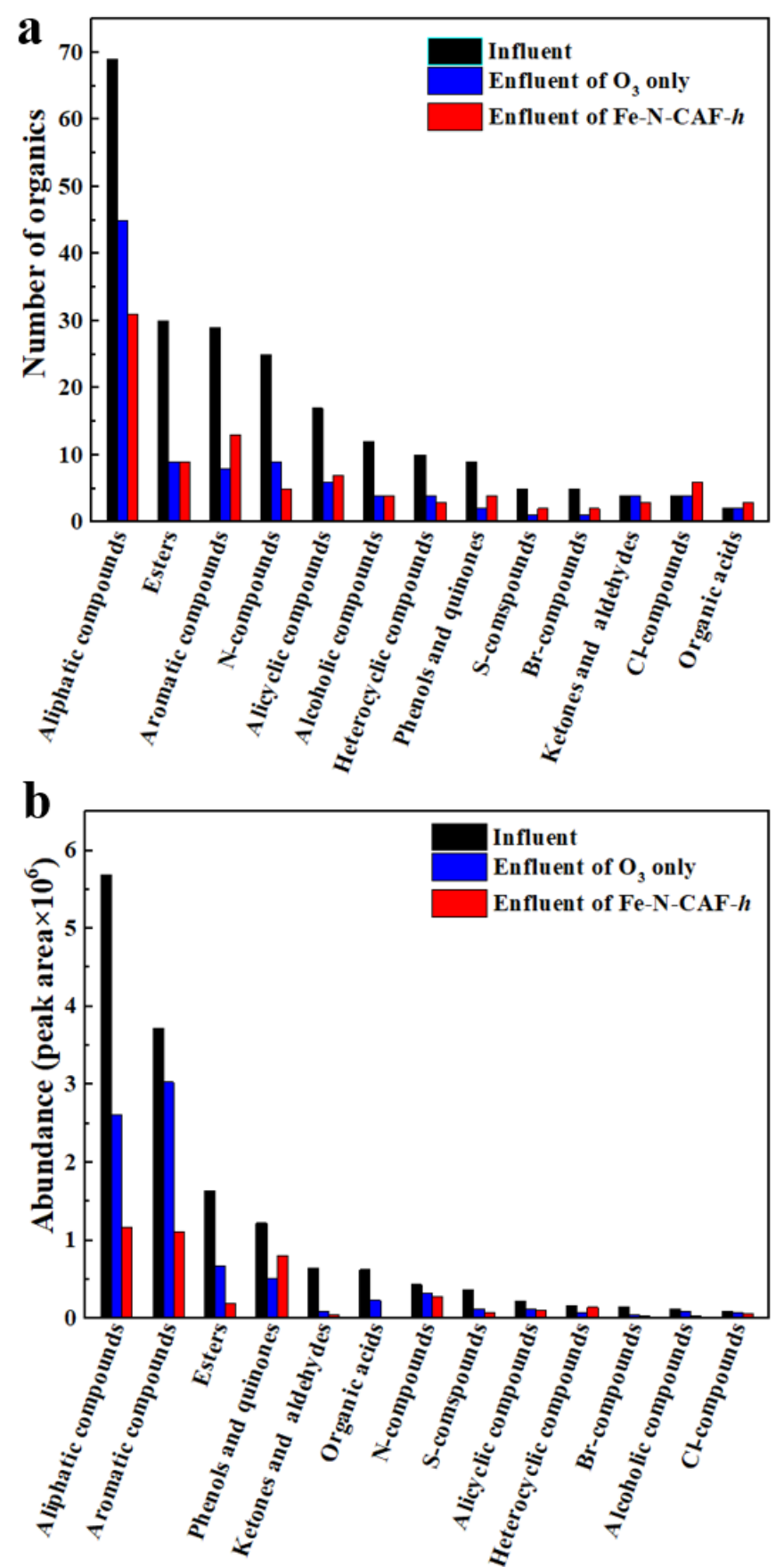

Figure S2. (a) Amount and (b) content of different organics in the coal-gasification secondary influent and effluent after $\mathrm{O}_{3}$ only and catalytic ozonation by Fe-N-CAF- $h$. Conditions: $250 \mathrm{~mL}$ coal-gasification wastewater with COD $160 \mathrm{mg} \mathrm{L}^{-1}$, gas flow rate $1.0 \mathrm{~L} \mathrm{~min}^{-1}, \mathrm{O}_{3}$ concentration $10 \mathrm{mg} \mathrm{L}^{-1}$, catalyst addition $4.0 \mathrm{~g} \mathrm{~L}^{-1}$, and initial $\mathrm{pH}$ 7.1. 

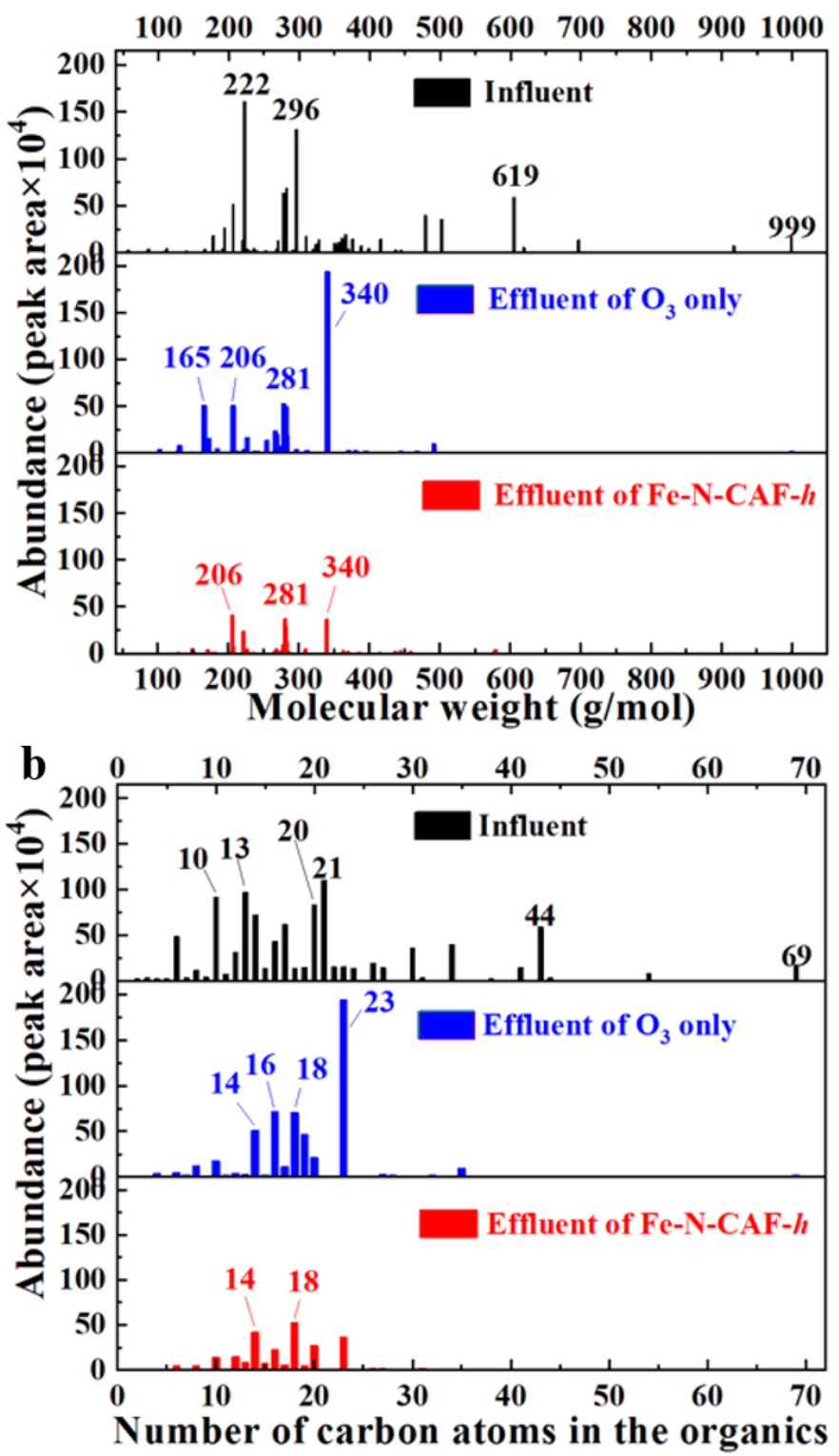

Figure S3. Distribution of organics with different (a) molecular weights (M.W.) and (b) numbers of carbon atoms in coal-gasification secondary influent and effluent after $\mathrm{O}_{3}$ only and catalytic ozonation by Fe-N-CAF- $h$. Conditions: $250 \mathrm{~mL}$ coal-gasification wastewater with COD $\sim 160 \mathrm{mg} \mathrm{L}^{-1}$, gas flow rate $1.0 \mathrm{~L} \mathrm{~min}^{-1}, \mathrm{O}_{3}$ concentration $10 \mathrm{mg}$ $\mathrm{L}^{-1}$, catalyst addition $4.0 \mathrm{~g} \mathrm{~L}^{-1}$, and initial $\mathrm{pH} 7.1$.

Discussion. In order to better illustrate the degradation of organic compounds, the number and abundance of organic types, molecular weight and number of carbon atoms were detected. Figure S2a showed that the number of organic types decreased under pure ozonation and catalytic ozonation, indicating that some of the organics were oxidized into $\mathrm{CO}_{2}$ and were completely mineralized. The abundance of different organic types under catalytic ozonation of Fe-N-CAF- $h$ was lower than $\mathrm{O}_{3}$ alone (Figure S2b). Figure S3a showed that the molecular weights of organic matters in the effluent decreased significantly under $\mathrm{O}_{3}$ alone and catalytic ozonation. The molecular 
weights of the organic matters in the two effluents were mainly between 200-340 $\mathrm{g} \mathrm{mol}^{-}$ ${ }^{1}$, and the organic matters with molecular weights above $350 \mathrm{~g} \mathrm{~mol}^{-1}$ almost disappeared. Moreover, catalytic ozonation of Fe-N-CAF- $h$ had a better degradation on the organics with molecular weights of 200-340 $\mathrm{g} \mathrm{mol}^{-1}$. Figure S3b showed the similar results in carbon atom number. The carbon atoms of the organic matters in the two effluents were mainly between 10-23, and the organic matters with over 25 carbons almost disappeared. The free radicals produced by Fe-N-CAF- $h$ catalytic ozonation could effectively break the carbon chain, and thus further reduce the molecular weights and carbon atom numbers of organic pollutants.

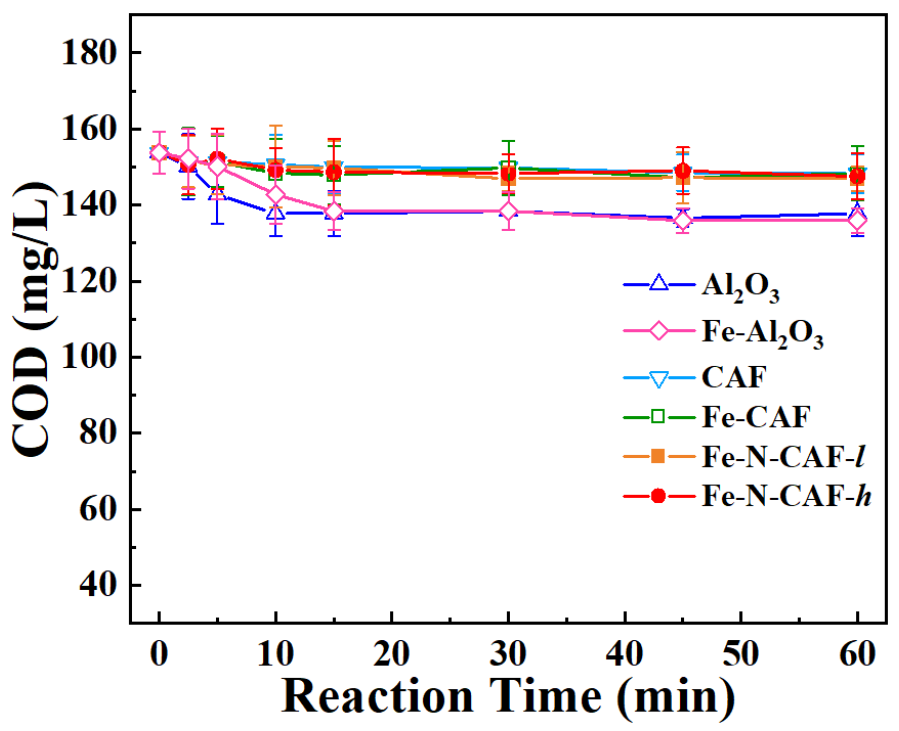

Figure S4. The adsorption of COD by different catalysts. Conditions: coal-gasification wastewater $250 \mathrm{~mL}$ with COD $160 \mathrm{mg} \mathrm{L}^{-1}$, catalyst addition $4.0 \mathrm{~g} \mathrm{~L}^{-1}$, gas flow rate 1.0 $\mathrm{L} \mathrm{min}^{-1}$, and initial $\mathrm{pH} 7.1$.

Discussion. As shown in Figure S4, the COD adsorption of CAF based catalysts was $\sim 3 \%\left(\sim 5 \mathrm{mg} \mathrm{L}^{-1}\right)$, which was negligible compared to the degradation with $\mathrm{O}_{3}$ (Figure 2a). Under the same system, the $\mathrm{COD}$ adsorption by $\mathrm{Al}_{2} \mathrm{O}_{3}$ and $\mathrm{Fe}-\mathrm{Al}_{2} \mathrm{O}_{3}$ were both $\sim 9 \%$ $\left(\sim 15 \mathrm{mg} \mathrm{L}^{-1}\right), 3$ times that of CAF based catalysts. The adsorption capacities of the CAF based catalysts were lower than that of $\mathrm{Al}_{2} \mathrm{O}_{3}$ and $\mathrm{Fe}-\mathrm{Al}_{2} \mathrm{O}_{3}$, while the degradation results of CAF based catalysts with ozone were better. Therefore, catalytic performance of the CAF based catalysts was much higher than that of $\mathrm{Al}_{2} \mathrm{O}_{3}$ and $\mathrm{Fe}-\mathrm{Al}_{2} \mathrm{O}_{3}$. 

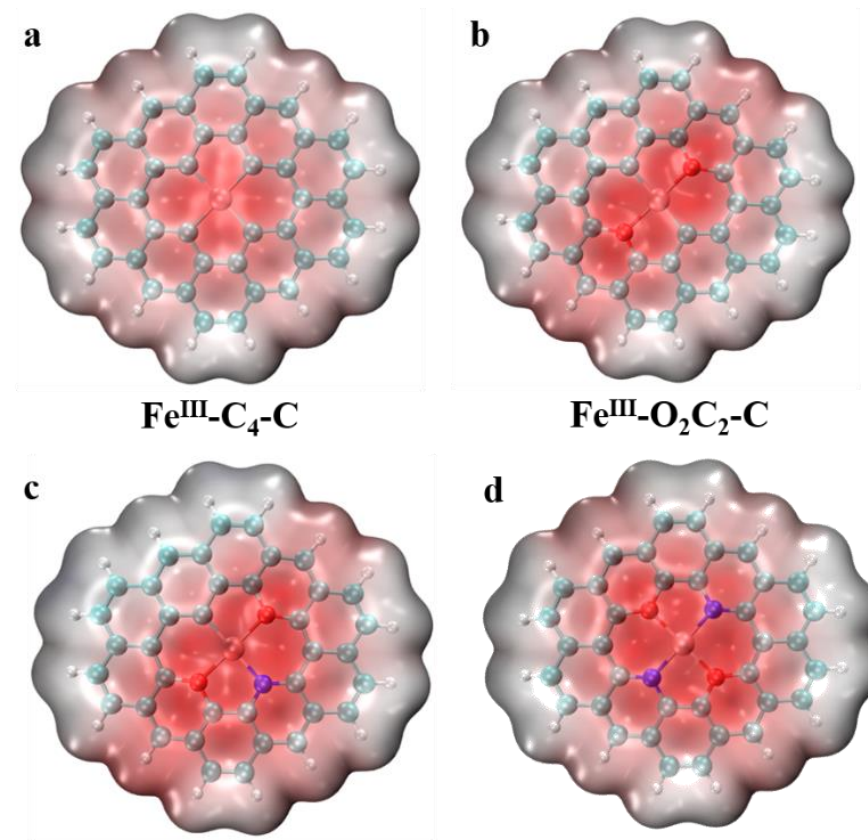

$\mathrm{Fe}^{\mathrm{III}}-\mathrm{O}_{2} \mathrm{C}_{2}-\mathrm{C}$

c

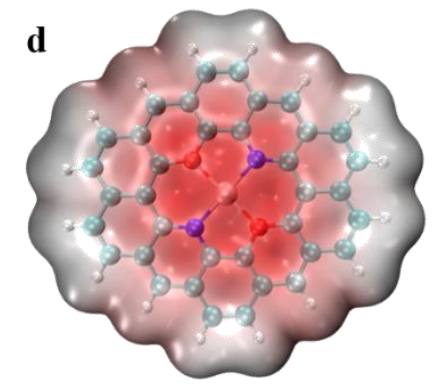

$\mathrm{Fe}^{\mathrm{III}}-\mathrm{NO}_{2} \mathrm{C}-\mathrm{C}$

$\mathrm{Fe}^{\mathrm{IIII}}-\mathrm{N}_{2} \mathrm{O}_{2}-\mathrm{C}$

$0.15 \rightleftarrows 0.35$

Figure S5. ESP maps of $\mathrm{Fe}^{\mathrm{III}}-\mathrm{C}_{4}-\mathrm{C}(\mathrm{a}), \mathrm{Fe}^{\mathrm{III}}-\mathrm{O}_{2} \mathrm{C}_{2}-\mathrm{C}(\mathrm{b}), \mathrm{Fe}^{\mathrm{III}}-\mathrm{NO}_{2} \mathrm{C}-\mathrm{C}$ (c) and $\mathrm{Fe}^{\mathrm{III}}-$ $\mathrm{N}_{2} \mathrm{O}_{2}-\mathrm{C}(\mathrm{d})$.

Discussion. According to some previous studies, $\mathrm{Fe}^{\mathrm{II}}$ was considered as a better electron donor than $\mathrm{Fe}^{\mathrm{III}}$ in ozone decomposition, while many of them were metal ion systems, like Fenton. ${ }^{4,5}$ Additionally, some matters with higher Fe valance, including $\mathrm{Fe}_{3} \mathrm{O}_{4}$ and $\mathrm{FeOOH}$, were reported to have good generation of free radicals, which was a metallic oxide system. ${ }^{6,7}$ These systems were different from Fe-N-C systems. In this paper, the active site of the Fe was not only due to the Fe itself, but also partly attributed to the $\mathrm{N}$ and $\mathrm{O}$ atoms with high electronegativity. The ESP distributions (Figure S5) showed that the central ESP of $\mathrm{Fe}^{\mathrm{III}}-\mathrm{N}_{2} \mathrm{O}_{2}-\mathrm{C}$ was more positive than $\mathrm{Fe}^{\mathrm{III}}-\mathrm{C}_{4}-\mathrm{C}$. Thus, the central Fe with $\mathrm{N}$ carried more positive charges, which could promote the process of interaction with ozone. 

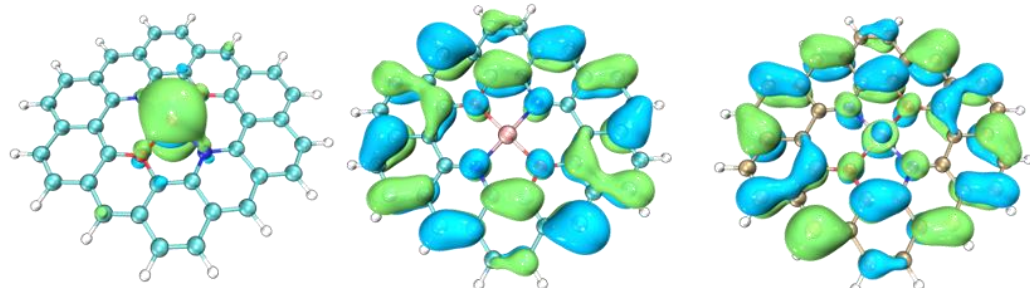

$\mathrm{Fe}^{\mathrm{II}}-\mathrm{N}_{2} \mathrm{O}_{2}-\mathrm{C}$

$\mathrm{Fe}^{\mathrm{III}}-\mathrm{N}_{2} \mathrm{O}_{2}-\mathrm{C}$

$\mathrm{Fe}^{\mathrm{II}}-\mathrm{N}_{2} \mathrm{O}_{2}-\mathrm{C}$

LUMO $=-0.146$ a.u.

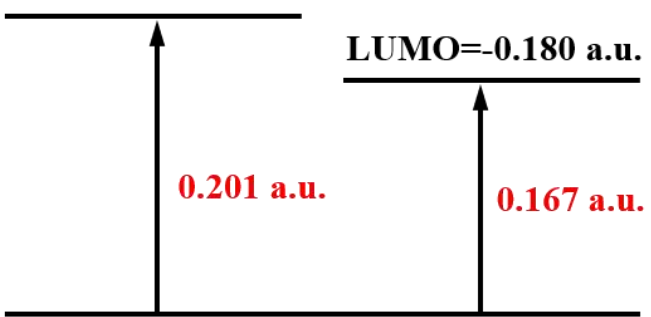

HOMO=-0.347 a.u.

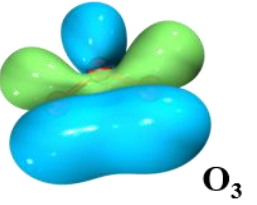

HOMO=-0.193 a.u.
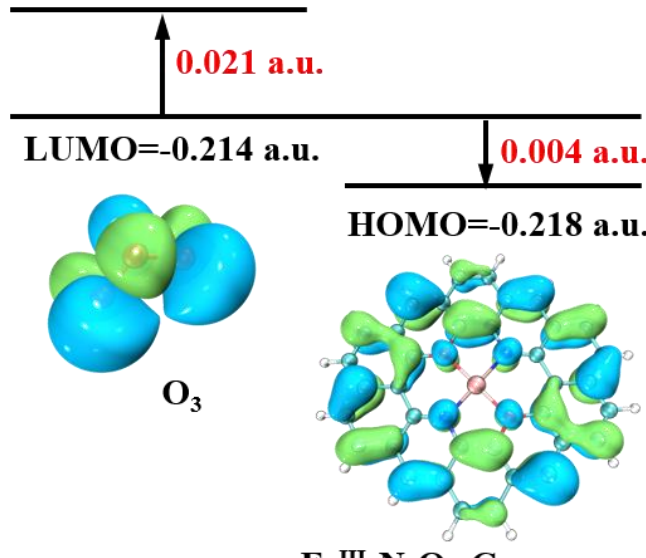

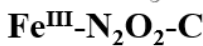

Figure S6. HOMO and LUMO distributions of $\mathrm{O}_{3}, \mathrm{Fe}^{\mathrm{II}}-\mathrm{N}_{2} \mathrm{O}_{2}-\mathrm{C}$ and $\mathrm{Fe}^{\mathrm{III}}-\mathrm{N}_{2} \mathrm{O}_{2}-\mathrm{C}$. HOMO-LUMO gaps between $\mathrm{O}_{3}$ and $\mathrm{Fe}-\mathrm{N}_{2} \mathrm{O}_{2}-\mathrm{C}$. 


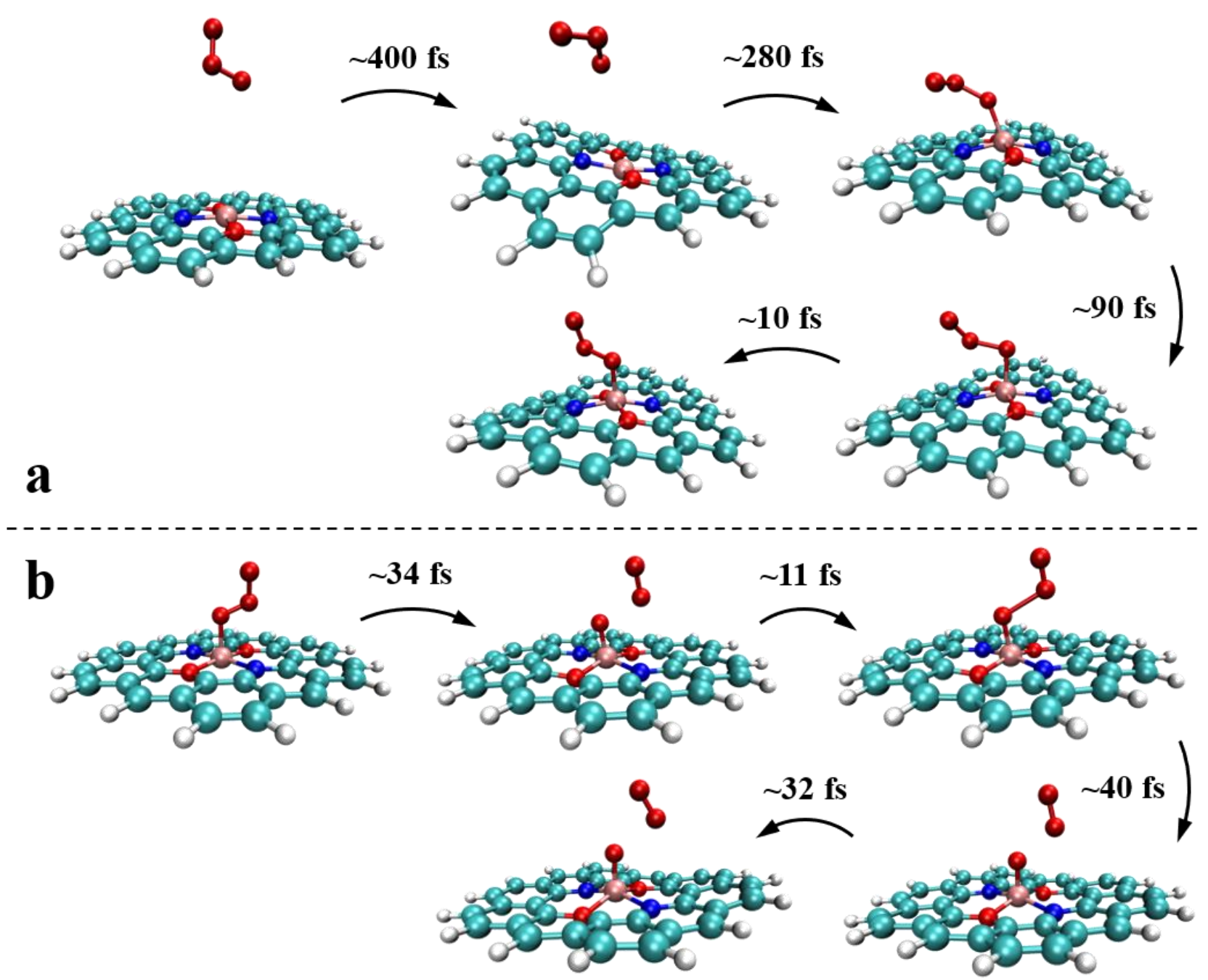

Figure S7. (a) Dynamic movement of $\mathrm{O}_{3}$ at an initial distance of $\sim 5.6 \AA$ from the $\mathrm{Fe}^{\mathrm{II}}-\mathrm{N}_{2} \mathrm{O}_{2}-\mathrm{C}$. (b) Decomposition process of $\mathrm{O}_{3}$ on $\mathrm{Fe}^{\mathrm{II}}-\mathrm{N}_{2} \mathrm{O}_{2}-\mathrm{C}$. 


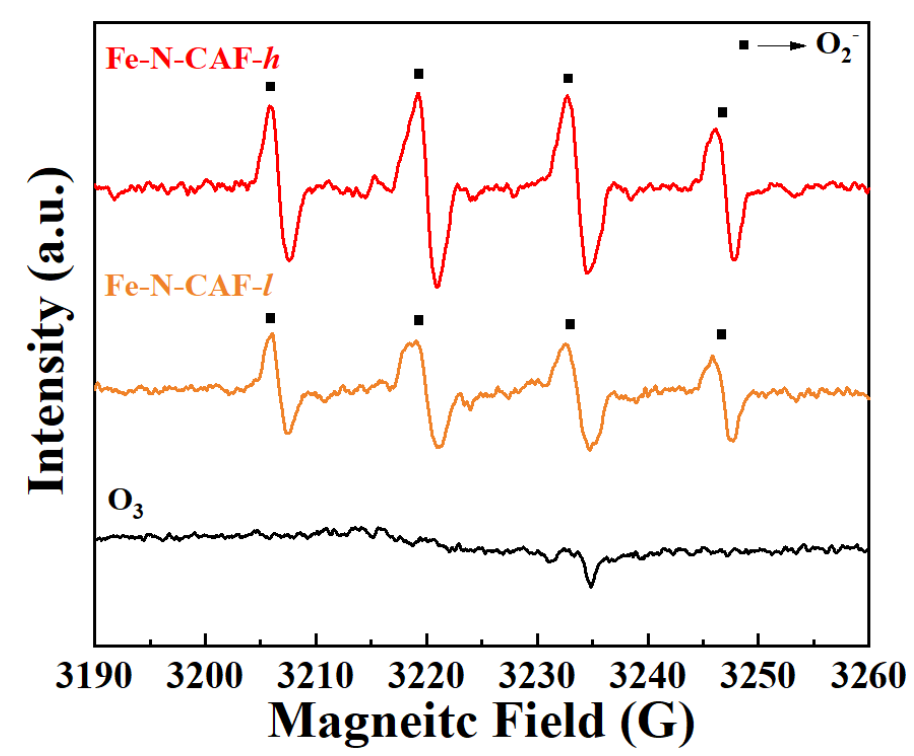

Figure S8. EPR results with DMPO and DMSO. Condition: DMPO $(100 \mathrm{mM})$ addition $2 \mu \mathrm{L}$ per $0.1 \mathrm{~mL}$ reaction solution (DMSO), $\mathrm{O}_{3}$ concentration $10 \mathrm{mg} \mathrm{L}^{-1}$, and catalyst addition $1.0 \mathrm{~g} \mathrm{~L}^{-1}$.
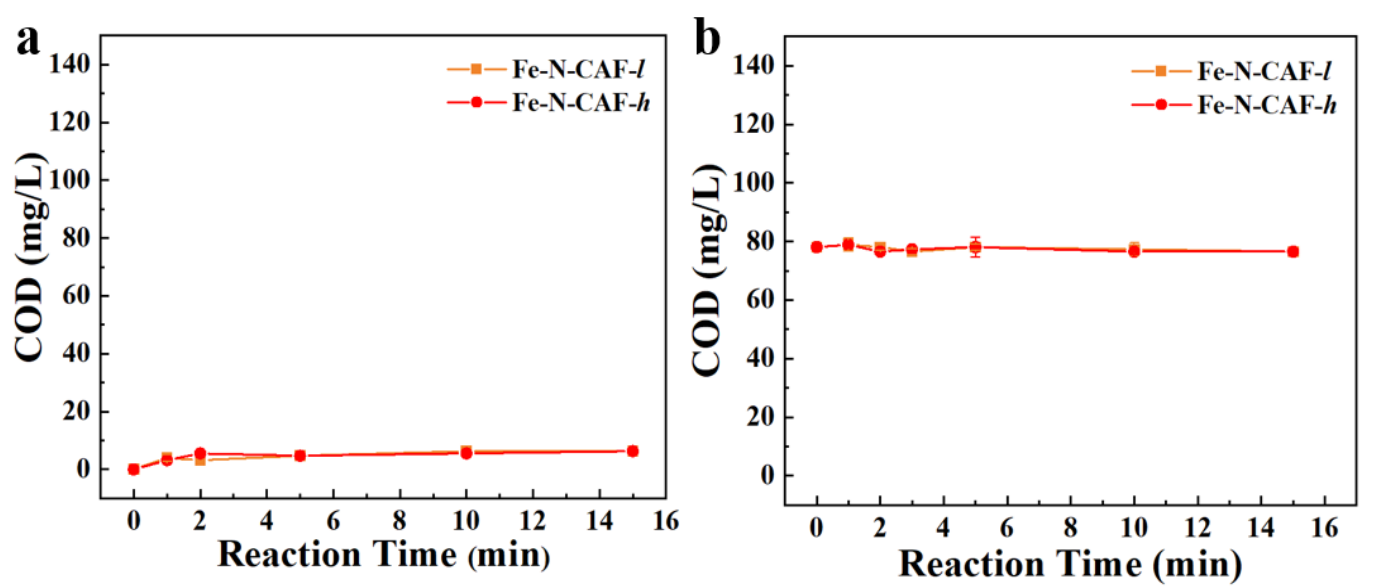

Figure S9. (a) The adsorption of oxidized products by Fe-N-CAF- $l$ and Fe-N-CAF- $h$. Conditions: $250 \mathrm{~mL}$ DI water with $4.0 \mathrm{~g} \mathrm{~L}^{-1}$ used catalyst under ultrasonic vibration. (b) The adsorption of the pre-ozonated wastewater by Fe-N-CAF- $l$ and Fe-N-CAF- $h$. Conditions: $250 \mathrm{~mL}$ pre-ozonated wastewater with $4.0 \mathrm{~g} \mathrm{~L}^{-1}$ catalyst.

Discussion. In order to test the adsorption of oxidized products, catalytic ozonation was performed in gasification wastewater for $30 \mathrm{~min}$. Catalysts were then filtrated and added in $250 \mathrm{ml}$ DI water under ultrasonic concussion. Water was sampled over time to measure COD content. Figure S9a showed the adsorption of oxidized products (COD) was only $\sim 6 \mathrm{mg} \mathrm{L}^{-1}$, which was a tiny portion. To further determine the adsorption products, the coal-gasification secondary effluent was firstly pre-aerated for $60 \mathrm{~min}$ under pure ozone. Then, the wastewater was shaken and stood for 12 hours until the 
dissolved ozone was completely gone. At last, the catalyst was added to test the adsorption capacity. Figure S9b showed that the adsorption of the pre-ozonated wastewater (COD) was only $\sim 5 \mathrm{mg} \mathrm{L}^{-1}$, which was a very small portion.
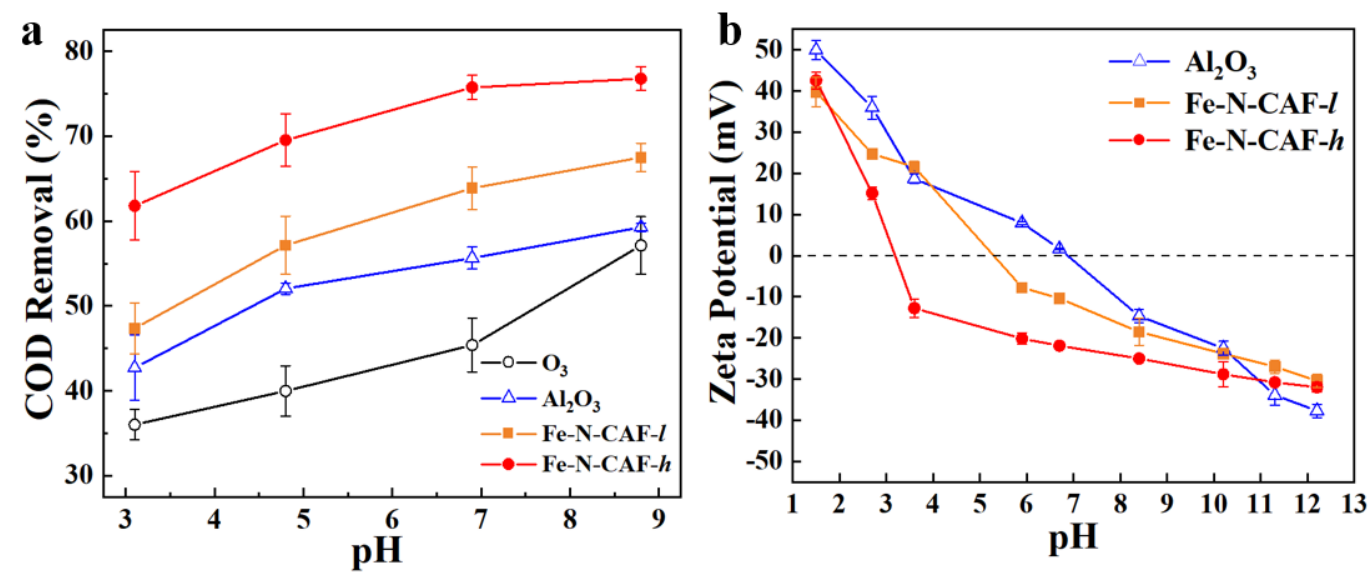

Figure S10. (a) The pH influence on COD removal by $\mathrm{O}_{3} /$ catalysts and $\mathrm{O}_{3}$ alone. (b) The detection of Zeta potentials of $\mathrm{Al}_{2} \mathrm{O}_{3}, \mathrm{Fe}-\mathrm{N}-\mathrm{CAF}-l$ and Fe-N-CAF- $h$. Conditions: coal-gasification wastewater $250 \mathrm{~mL}$ with COD $\sim 160 \mathrm{mg} \mathrm{L}^{-1}$, catalyst addition $4.0 \mathrm{~g} \mathrm{~L}^{-}$ 1 , gas flow rate $1.0 \mathrm{~L} \mathrm{~min}^{-1}, \mathrm{O}_{3}$ concentration $10 \mathrm{mg} \mathrm{L}^{-1}$, reaction time $60 \mathrm{~min}$, and the $\mathrm{pH}$ was buffered to $3.1,4.8,6.9$ and 8.8 for each test.

Discussion. At all pHs, the COD removal was in a descending order: Fe-N-CAF- $h>$ Fe-N-CAF- $l>\mathrm{Al}_{2} \mathrm{O}_{3}>\mathrm{O}_{3}$ (Figure $\mathrm{S} 10$ a). Specifically, at pH 3.1, COD removal of Fe$\mathrm{N}-\mathrm{CAF}-h$ was $62 \%$, higher than $\mathrm{O}_{3}(36 \%), \mathrm{Al}_{2} \mathrm{O}_{3}(43 \%)$ and Fe-N-CAF-l $(47 \%)$. Similar trends were achieved at other pHs. Moreover, COD removal increased with the increase of $\mathrm{pH}$. It might be due to the difference in isoelectric point of different catalysts The detection of Zeta potentials (Figure S10b) showed that Fe-N-CAF- $h$ achieved the lowest isoelectric point (3.2), compared with Fe-N-CAF-l (5.4) and $\mathrm{Al}_{2} \mathrm{O}_{3}$ (6.9). It indicated that at the same $\mathrm{pH}$, the surface of Fe-N-CAF- $h$ might adsorb more $\mathrm{OH}^{-}$, which could promote the catalytic ozonation process. ${ }^{8,9}$ Therefore, Fe-N-CAF- $h$ had better catalytic performance. 

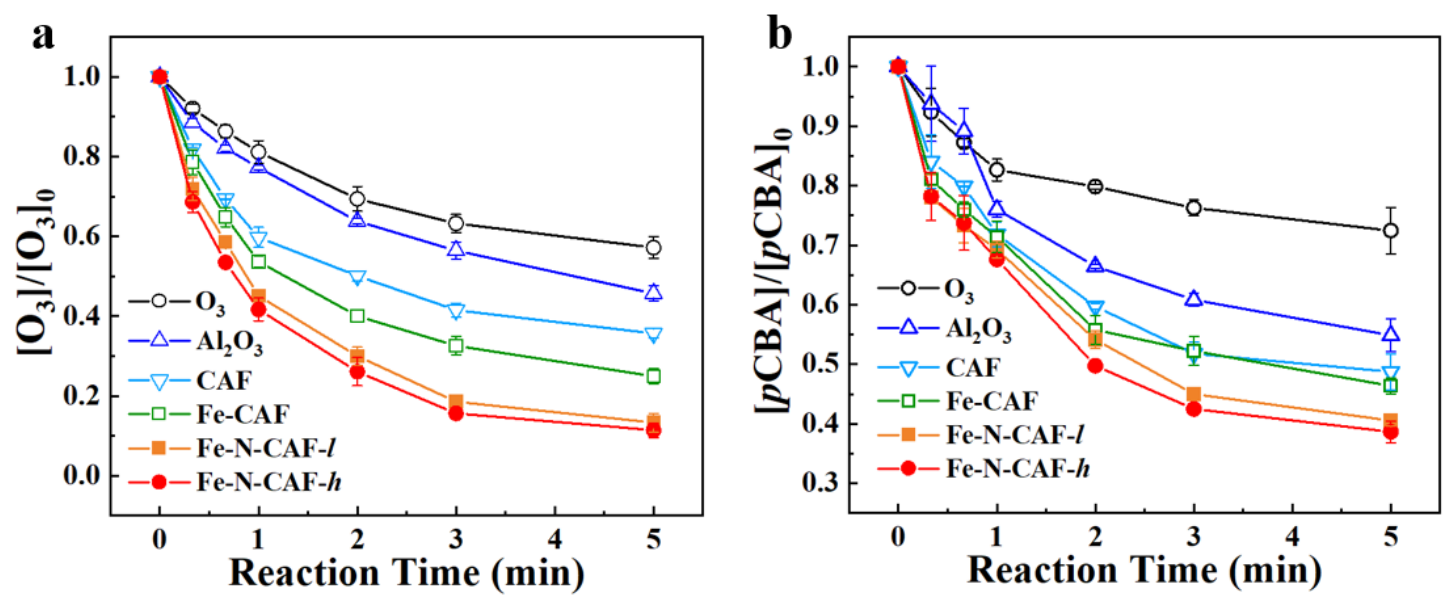

Figure S11. (a) The ozone decomposition by $\mathrm{O}_{3} /$ catalysts and $\mathrm{O}_{3}$ alone. (b) The degradation of $p \mathrm{CBA}$ by $\mathrm{O}_{3} /$ catalysts and $\mathrm{O}_{3}$ alone. Conditions: $p \mathrm{CBA}$ concentration $0.5 \mu \mathrm{M}$, initial $\mathrm{O}_{3}$ concentration $\sim 29 \mu \mathrm{M}$, catalyst addition $0.75 \mathrm{~g} \mathrm{~L}^{-1}$, and $\mathrm{pH}$ buffered at 6.7 .

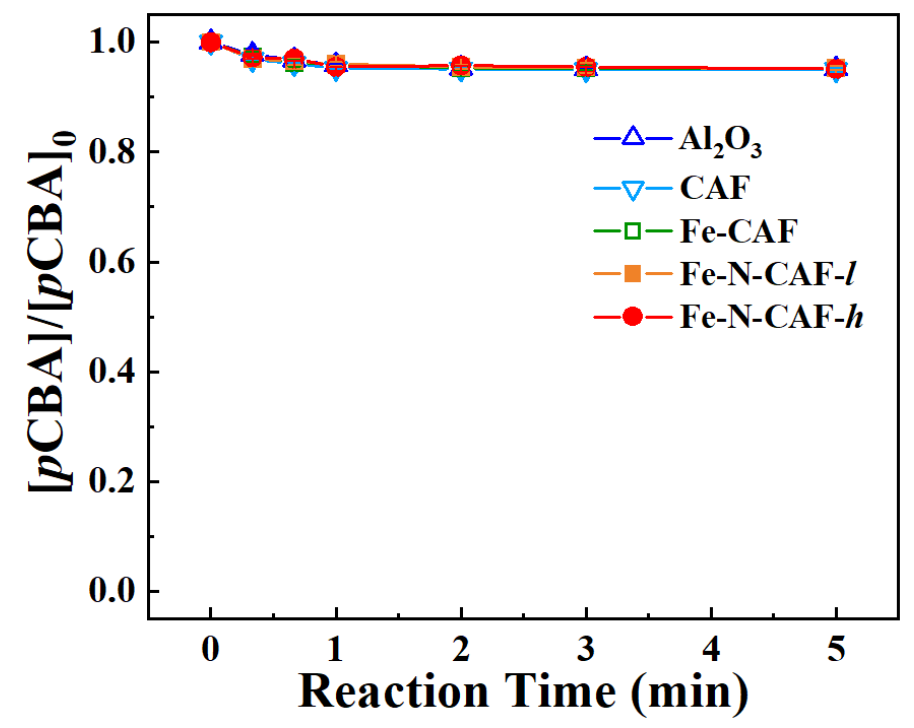

Figure S12. The adsorption of $p$ CBA by different catalysts. Conditions: stock volume $250 \mathrm{~mL}$ with $p \mathrm{CBA}$ concentration $0.5 \mu \mathrm{M}$, catalyst addition $0.75 \mathrm{~g} \mathrm{~L}^{-1}$, and $\mathrm{pH}$ buffered at 6.7 . 


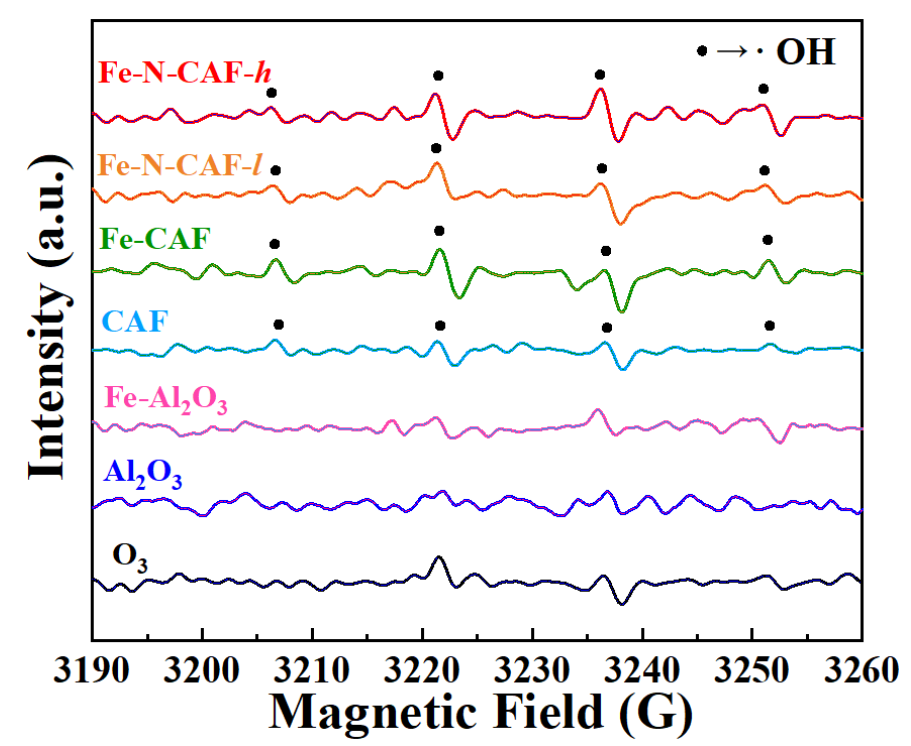

Figure S13. EPR results employing DMPO and DI water. Condition: DMPO (100 mM) addition $2 \mu \mathrm{L}$ per $1 \mathrm{~mL}$ reaction solution (DI water), $\mathrm{O}_{3}$ concentration $10 \mathrm{mg} \mathrm{L}^{-1}$, and catalyst addition $1.0 \mathrm{~g} \mathrm{~L}^{-1}$.
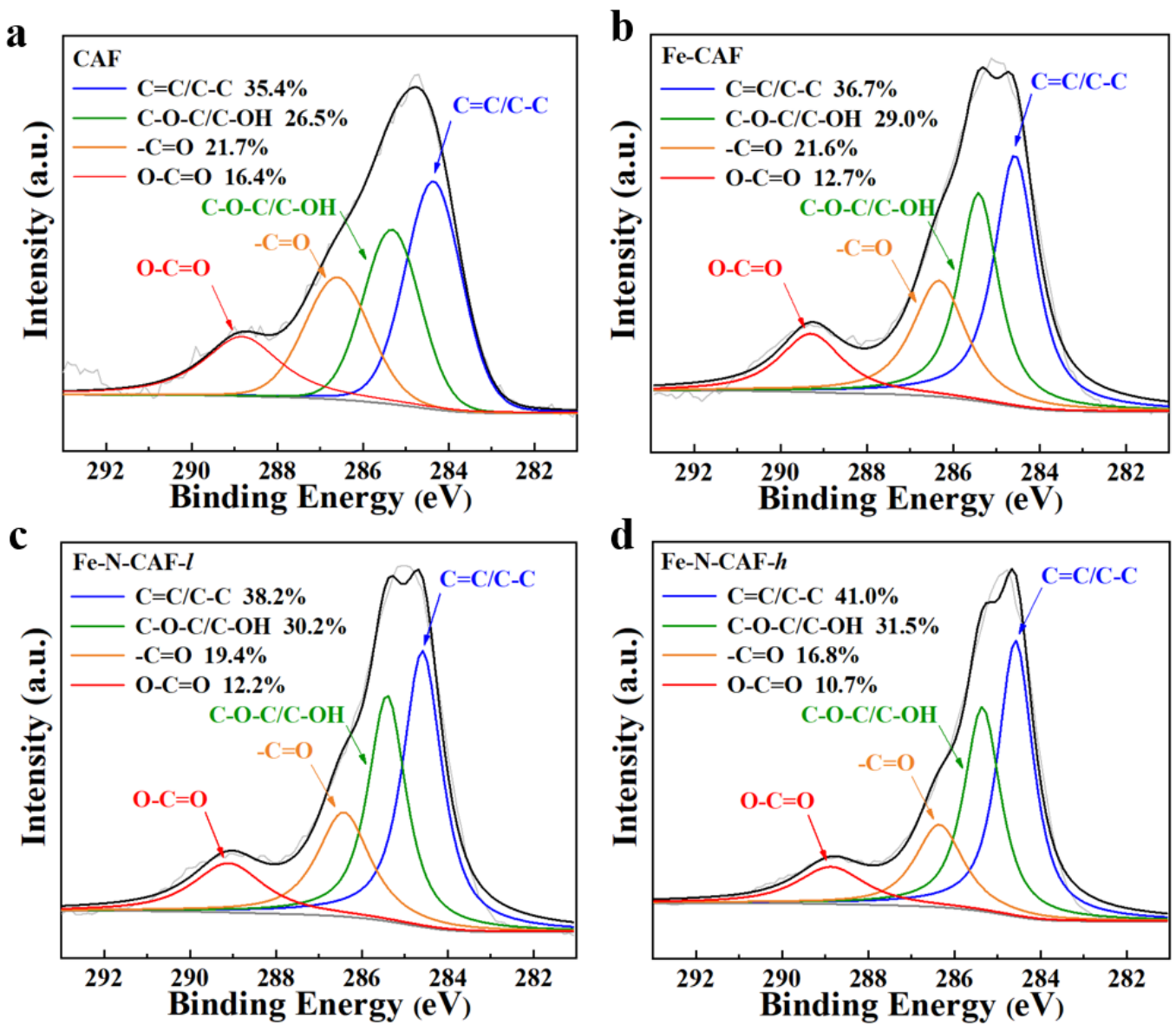

Figure S14. High-resolution XPS survey of C1s for CAF (a), Fe-CAF (b), Fe-N-CAF$l(\mathrm{c})$ and Fe-N-CAF- $h(\mathrm{~d})$. 


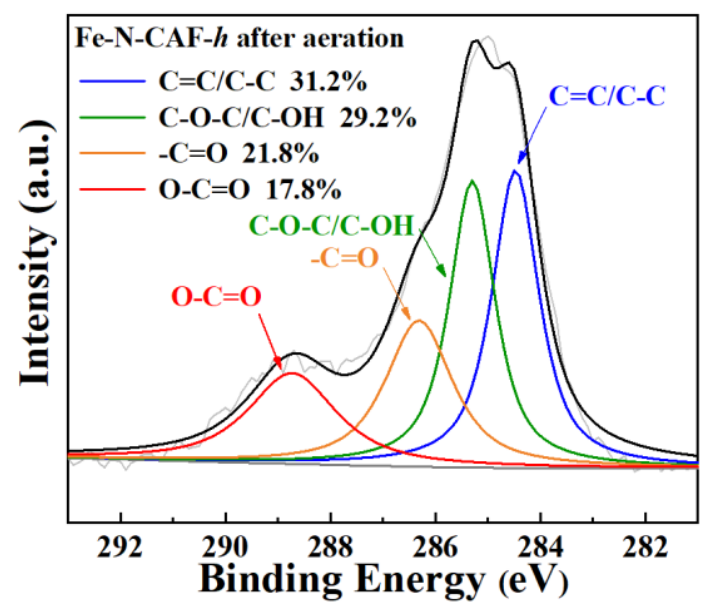

Figure S15. High-resolution XPS survey of C1s for Fe-N-CAF- $h$ after aeration.

Discussion. In order to illustrate the role of adsorbed hydroxyl groups on the catalyst surface, high-resolution XPS survey of C1s for each catalyst was conducted. Figure S14 showed that the difference of hydroxyl group contents for each catalyst was not significant. The hydroxyl group contents after ozone aeration (Figure S15) did not change dramatically compared with that before aeration (Figure S14d). It indicated that in the metal-CAF systems, hydroxyl groups might not be the main substances involved in ozonation reactions. The previous study showed that under system of carbon only, the hydroxyl groups played an important role in the catalytic ozonation process. After catalytic ozonation, carboxyl group content increased and it hindered the maintenance of catalytic stability. ${ }^{10}$ However, in the Fe-N-CAF system, Fe-N active sites played a more important role to catalytic performance. 

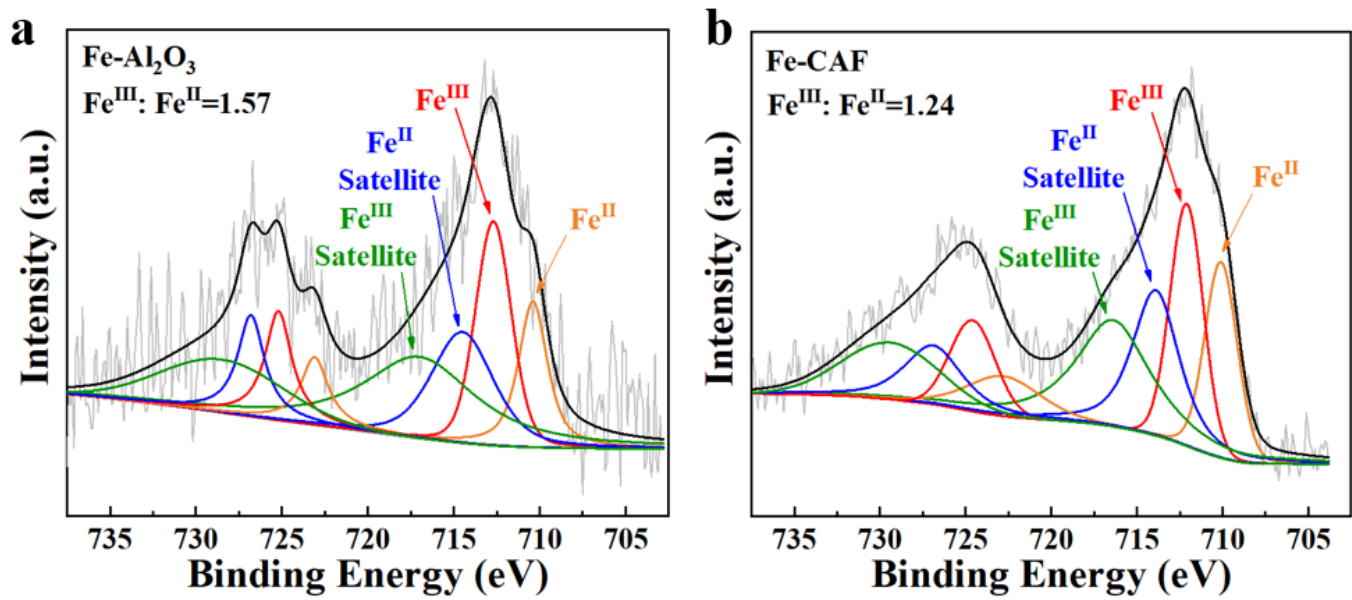

Figure S16. High-resolution XPS survey of $\mathrm{Fe} 2 \mathrm{p}$ for $\mathrm{Fe}_{-} \mathrm{Al}_{2} \mathrm{O}_{3}$ (a) and $\mathrm{Fe}-\mathrm{CAF}(\mathrm{b})$.

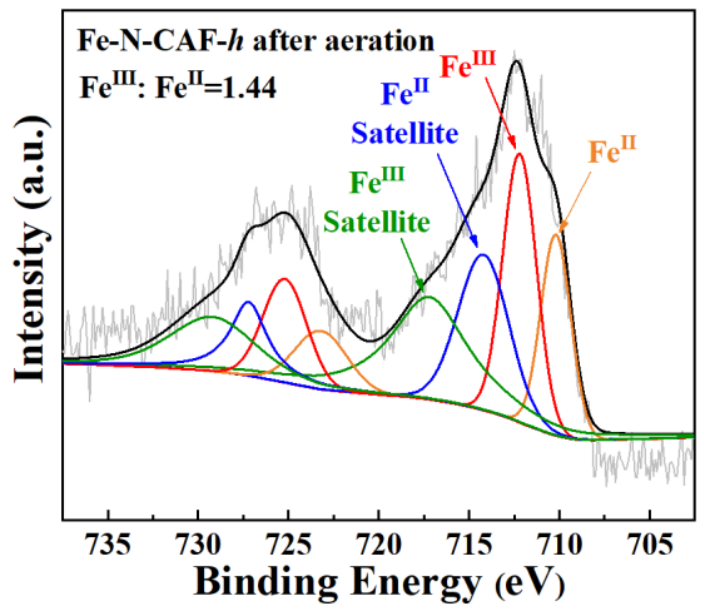

Figure S17. High-resolution XPS survey of Fe2p for Fe-N-CAF- $h$ after aeration.

Discussion. Figure S17 showed that Fe ${ }^{\mathrm{III}}$ : Fe ${ }^{\mathrm{II}}$ of used Fe-N-CAF- $h$ was 1.44 , increased by $3 \%$ from new Fe-N-CAF- $h$ of 1.39 (Figure 1f). The catalysis performance did not decline after ozone aeration (Figure $2 \mathrm{f}$ ). Therefore, the minor rise of $\mathrm{Fe}^{\mathrm{III}}: \mathrm{Fe}^{\mathrm{II}}$ rate after the ozonation process might be beneficial to maintain the catalytic activity, since the catalyst with higher $\mathrm{Fe}^{\mathrm{III}}$ content was better than that with lower $\mathrm{Fe}^{\mathrm{III}}$ content. 


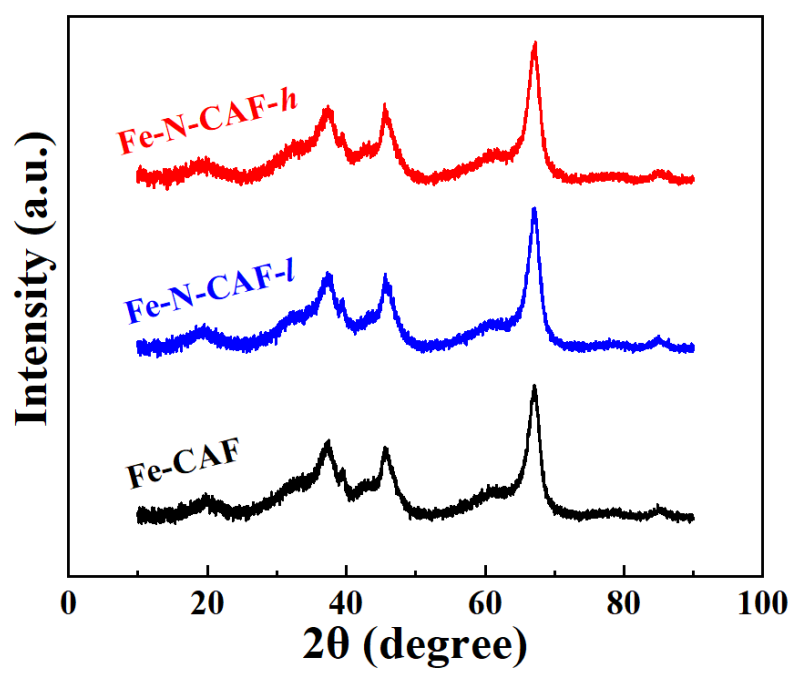

Figure S18. XRD results of Fe-CAF, Fe-N-CAF- $l$ and Fe-N-CAF- $h$. 


\section{Reference}

1. Elovitz, M. S.; Von Gunten, U., Hydroxyl radical/ozone ratios during ozonation processes. I. The R(ct) concept. Ozone: Science and Engineering 1999, 21 (3), 239-260. 2. Pi, Y.; Schumacher, J.; Jekel, M. J. O. S.; Engineering, The Use of paraChlorobenzoic Acid (pCBA) as an Ozone/Hydroxyl Radical Probe Compound. 2005, 27 (6), 431-436.

3. Bader, H., Determination of Ozone In Water By The Indigo Method: A Submitted Standard Method. Ozone-science \& Engineering - OZONE-SCI ENG 1982, 4, 169-176. 4. Arslan, I.; Balcioglu, I. A.; Tuhkanen, T., Advanced treatment of dyehouse effluents by $\mathrm{Fe}(\mathrm{II})$ and $\mathrm{Mn}$ (II)-catalyzed ozonation and the $\mathrm{H} 2 \mathrm{O} 2 / \mathrm{O}-3$ process. Water Science and Technology 2000, 42 (1-2), 13-18.

5. Malvestiti, J. A.; Cruz-Alcalde, A.; López-Vinent, N.; Dantas, R. F.; Sans, C., Catalytic ozonation by metal ions for municipal wastewater disinfection and simulataneous micropollutants removal. Applied Catalysis B: Environmental 2019, 259. 6. Lv, A.; Hu, C.; Nie, Y.; Qu, J., Catalytic ozonation of toxic pollutants over magnetic cobalt-doped Fe3O4 suspensions. Applied Catalysis B-Environmental 2012, $117,246-252$.

7. Sui, M.; Sheng, L.; Lu, K.; Tian, F., FeOOH catalytic ozonation of oxalic acid and the effect of phosphate binding on its catalytic activity. Applied Catalysis $B$ Environmental 2010, 96 (1-2), 94-100.

8. Bezbarua, B. K.; Reckhow, D. A., Modification of the standard neutral ozone decomposition model. Ozone-Science \& Engineering 2004, 26 (4), 345-357.

9. Gardoni, D.; Vailati, A.; Canziani, R., Decay of Ozone in Water: A Review. OzoneScience \& Engineering 2012, 34 (4), 233-242.

10. Wei, K.; Wang, Z.; Ouyang, C.; Cao, X.; Liang, P.; Huang, X.; Zhang, X., A hybrid fluidized-bed reactor (HFBR) based on arrayed ceramic membranes (ACMs) coupled with powdered activated carbon (PAC) for efficient catalytic ozonation: A comprehensive study on a pilot scale. Water Research 2020, 173. 